\title{
Risk Assessment Method for Identification of Environmental Aspects and Impacts at Ore Processing Industry in Indonesia
}

\author{
Arif Susanto ${ }^{1,2 *}$, Nur Budi Mulyono² \\ 1 Doctorate Program in Environmental Science, School of Postgraduate Studies, Universitas Diponegoro, \\ 50241, Semarang, Indonesia \\ 2 School of Business and Management, Institut Teknologi Bandung, Indonesia, 40132, Bandung, Indonesia \\ * Corresponding author's e-mail: arifssnt@yahoo.com
}

\begin{abstract}
Ore processing industry in Indonesia applies the international standard of environmental management system based on ISO 14001:2015. The implementation of clause 6.1.2 requires every organization to identify the environmental aspects of its operations, as an initial step in environmental management. The objective of this research is to develop a structured approach in identifying the environmental aspects and impacts so that an evaluation on the risks, opportunities as well as severity of possible environmental impacts can be conducted. The employed methods involve life-cycle approach and risk assessment method with four-cell risk assessment matrix in environmental risk determination. The results of this risk assessment can give an overview of environmental aspects and impacts, so that control priority can be determined in order to reduce the risks.
\end{abstract}

Keywords: environmental aspects; environmental impacts; environmental management system; ISO 14001:2014; life-cycle approach; risk assessment.

\section{INTRODUCTION}

Ore processing industry is a company that operates in the field of copper and gold mining, and has operated since 1972 in Mimika Regency, Papua Province (Susanto et al, 2012; Susanto et al., 2017; Susanto et al., 2016a), and has a commitment to develop an Environmental Management System (EMS) that complies with ISO 14001 or SNI 19-14001 standards and since 1998, ore milling industry started formulating this environmental management system in order to comply with ISO 14001 standards (Susanto, 2017).

At the ore processing plant, the copper, gold and silver minerals are extracted using flotation technique that is commonly used by similar ore processing plants in the world. Initially, the ore rocks are milled until soft and mixed with water in large quantities on the mill machines. Later on, they are streamed into flotation tanks. Air bubbles and reagent are put into the flotation tanks that move from the bottom of the tanks towards the surface. In their way to the surface, these bubbles catch and collect the precious minerals from the surface of soft grains resulting from the crushed ore rocks. After they reach the surface, the bubbles turn into foams that are rich with precious minerals. The foams are then collected into concentrate pulps and sent through pipelines towards the dewatering plant. Dewatering process is done with a filter press and heating. The dry concantrates are in the form of black-colored soft sand, which is the final product of industry.

General business process is illustrated in Figure 1. According to clause 6.1.2 in ISO $14001: 2015$, ore processing industry is required to conduct identification of environmental aspects from its operations. The identification of environmental aspects and impacts is one of the initial processes in environmental management (Susanto, 2017). On the basis of the identification results, the important aspects in a process on each activity unit can be defined, so an environmental control and management planning program, as well as the follow up actions may be carried out. 


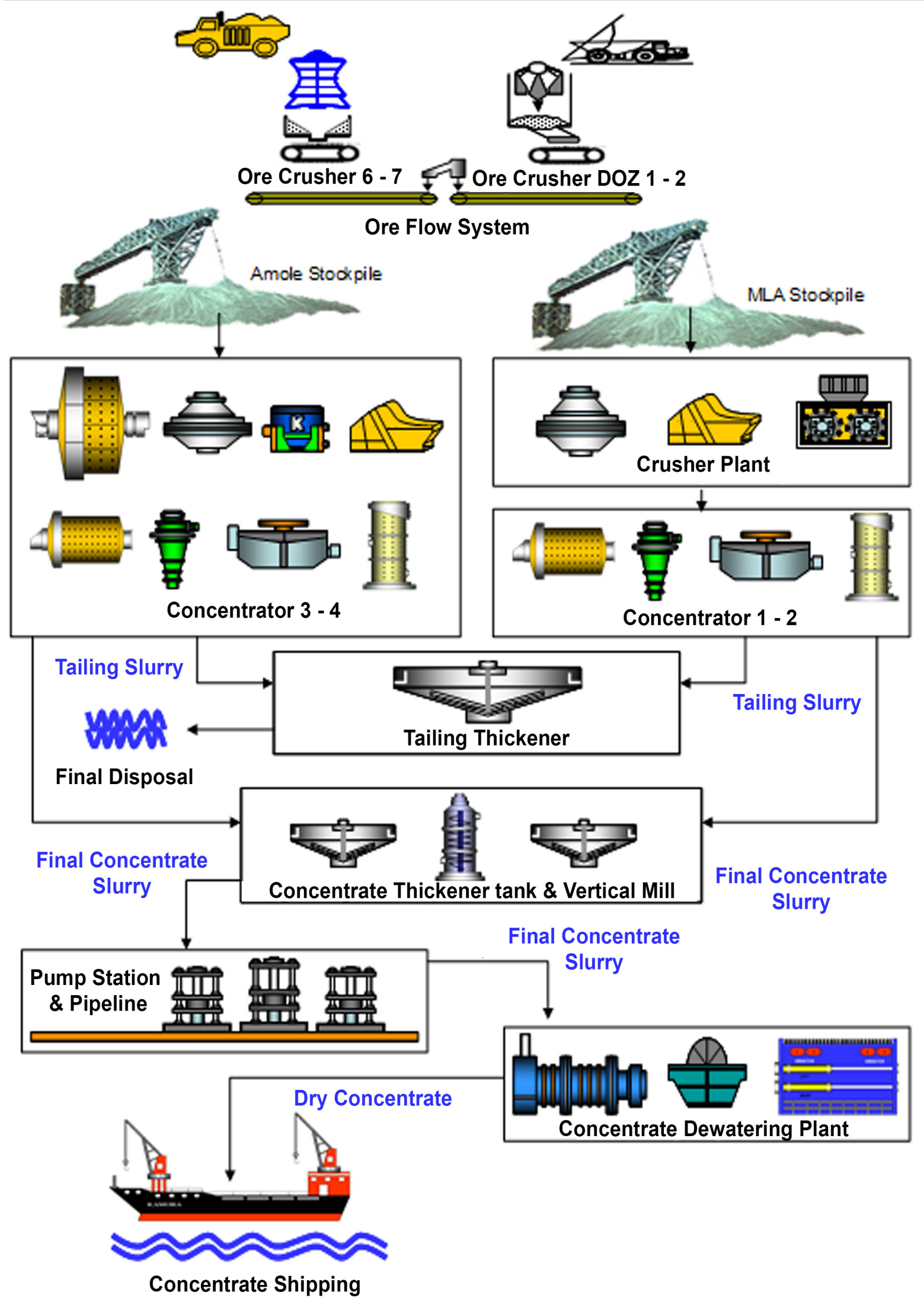

Figure 1. General business process 
The standard of EMS used by the ore processing industry has changed. The 2015 version of ISO 14001, which superseded the 2004 version, has been published and an organization is given a three-year transition period after the revision to migrate into the latest version of EMS. This is intended for use by organizations to manage their environmental responsibility in a systematic way that contributes to the environmental improvement approach in the units of production.

According to clause 6.1.2 in ISO 14001:2015, it is required to conduct an identification of environmental aspects from its operations. The identification of environmental aspects and impacts is one of the initial processes in environmental management (Susanto, 2017). On the basis of identification results, the important aspects in a process on each activity unit in ore processing plant can be defined, so an environmental control and management planning program, as well as the follow up actions in the important aspects handling can be taken.

The objective of this research is to obtain a structured approach in identifying environmental aspects and impacts so that a planning and evaluation of the risks, opportunities as well as severity level of environmental impacts that can possibly occur in ore processing industry can be carried out.

\section{METHODS}

Identification and determination of the environmental aspects and impacts, refers to risk assessment method (Bird \& Germain, 1996) with four-cells risk assessment matrix, and calculation of the life cycle according to the clause 6.1.2 of ISO 14001:2015 environmental management system standards (ISO, 2015). Meanwhile, life-cycle assessment, or life-cycle analysis, involves the continuous and interrelated stages in product system and/or services, starting from material procurement or making from natural resources to the final disposal (ISO, 2006a; ISO 2006b).

This risk assessment method considers normal, abnormal and emergency conditions that can possibly happen, and becomes a part of the method (ISO, 2015). Normal conditions refer to the regular or expected conditions from an organization activity or plan operation, while abnormal conditions refer to the unplanned or unexpected conditions that are not part of the organization operation plan, whereas the emergency condi- tions refer to unexpected or serious, urgent and sudden situations that require immediate action (Susanto, 2017).

\section{RESULTS AND DISCUSSIONS}

Environmental management system is a system that is dynamic and able to follow the dynamics or development on the related parties; therefore, organization has to be able to follow the development by ensuring that the environmental aspect list is always updated, either when there is a development from external factors like environmental regulation change or when it is done regularly to accommodate changes in the organization.

According to clause 6.1.2 in ISO 14001:2015, ore processing industry must guarantee that the aspects related to their important aspects are considered in defining environmental objectives, and keep paying attention to the following:

1. Considering life cycle in determining the environmental aspects and impacts by taking into account the changes including planned development, process and any modification.

2. Considering normal, abnormal and emergency conditions that may possibly happen.

3. Determining the method of defining important environmental aspects so that ore processing industry can make follow up programs and actions on the results of environmental aspects and impacts identification that have been done previously.

In ISO 14001:2015 standard implementation performance and indicators, there are several parameters and indicators of environmental management system performance stated from several items (Susanto \& Putro, 2017):

1. Significant environmental aspects. Ore processing industry shall identify the environmental aspects from its operational activities (Figure 1) according to the requirements and determine the environmental aspects that have a significant impact on the environment.Moreover, in order to ensure that the control is efficient in achieving targets, monitoring and measurement have to be conducted.

2. Compliance obligation. Compliance obligation consists of law regulations and other requirements, which regulate the obligations that must be complied, i.e. key parameters stated in the environmental documents such as Analy- 
sis on Environmental Impacts, environmental permits etc. ispepi Operational Planning and Control. In order to ensure that the environmental aspects are in line with their objectives, ore processing industry shall conduct monitoring and measurement from the operation activities, through monitoring on the standard operating procedures (SOP) compliance, abnormal operation condition, operation implementation to the incompetent personnels etc.

The identification result is a list of environmental aspects and impacts that cover the whole environmental aspects comprehensively, under normal, abnormal and emergency conditions, as well as all components explained per part of production activity etc. Environmental aspect is defined as part of the activity that interacts with the environment while the impact is the result of an aspect. In other words, there is a causeand-effect relation between the environmental aspects and impacts.

For example, kiln operation in lime production activity, where this lime is used as the material for production process to improve mineral recovery, is one of the main activities in the lime plant consisting of sub-activities that interact with environment or create impacts such as dust emission. Gas emission resulting from the calcination, such as $\mathrm{SO}_{\mathrm{X}}, \mathrm{NO}_{\mathrm{X}}$ and mainly particulate matter is environmental aspect that can create impacts in the form of air pollution. Meanwhile, other aspects from lime production activity, i.e. spent oil and diesel oil usage as in the case of lime production fuel mixer, can create impact such as oxidation gas emission (Susanto et al., 2016a).

Another example of aspects involves the laboratory activity in the form of metallurgy analysis that has sub-activity or environmental aspect like chemicals addition, fire assay waste generation (Susanto et al., 2013; Susanto et al. 2015). If the impact creation process is examined, these activities are categorized as the environmental aspects that create land and water pollution impact from hazardous waste generation and air pollution from the prospective exhaust dust release which can potentially become a hazard on occupational health. It can also be seen here that a few aspects can cause one or several types of environmental impacts, i.e. air pollution, water pollution and/or land pollution.

The aspects in abnormal condition of activity can exist when, for example, machinery and equipment maintenance activities are conducted so the environmental impacts are not from normal activities, i.e. spent oil and grease spills, used spare part disposal, chemically contaminated waste, etc. Meanwhile, the emergency conditions contribute environmental aspects in the form of particulate 'blow up' to the air due to operational temperature that is too high, which may exceed the threshold values stated in the environmental permits. These three types of conditions (normal, abnormal and emergency) must be listed and differentiated between the two conditions, where emergency conditions involve abnormal conditions that gives sudden huge impacts and cannot be prevented except to reduce the impacts aftermath (Susanto, 2017).

The identification must be done, not merely limited to the operational activities related to the largest waste source, but also concerning the aspects of their products. The examples that have been mentioned above are the aspects that appear from main production activities. On the other hand, the aspects from products have a wider coverage, such as the products when pumped from mill tower through concentrate pipeline system, dewatering process, dry concentrate storage in barns, and concentrate product loading to the transporting ship. This process can cause environmental impact. Land and water pollution appear from the potential of pipeline leak, air pollution from concentrate particles and gas emission from the oxidation of spent oil and diesel fuel mix (Susanto et al., 2016a).

Various types of impacts can clearly result from those aspects and have risk category, so this is an example of product aspect classified as a significant aspect. After it is clear for identification coverage, ore processing industry can conduct evaluation on the all aspects to determine the ones classified as important, or the ones that will be assigned handling priority based on their risk study. This stage is critical and strongly de-

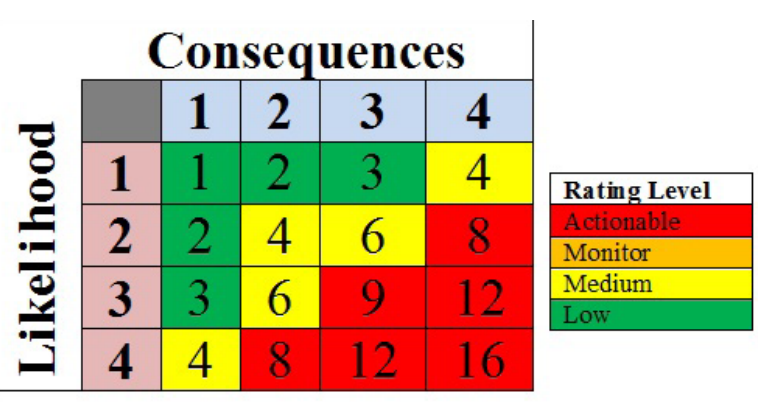

Figure 2. Four-Cells Risk Matrix 
termines the success and effectiveness of environmental management system implementation. In ISO 14001:2015 environmental management system standard, a risk assessment method and evaluation, including whether it has to be with qualitative or quantitative method is not required; however, what needs to be developed is a method that is appropriate with the complication level of the organization activity itself. In this risk study, risk assessment method using four-cells risk matrix is used, as illustrated in Figure 3.

\section{COMPLIANCE OBLIGATION EVALUATION}

Compliance obligation refers to two items, i.e. law regulation and other requirements. Law regulation requirements cover: (1) requirements from government body or other relevant authorities; (2) international, national and local law and regulations; (3) requirements stated in the permits; (4) orders or regulations from law bodies; (5) court or administrative court decisions. Meanwhile, other requirements are the requirements identified by respective and related parties with the environmental management system where organization must comply and/or choose to adopt, for example agreements with community of nongovernmental organization; agreements woth public authority or customers, voluntary labelling or environmental commitment; agreements that exist based on the contract agreements with organization and relevant organization standards.

\section{RISK ASSESSMENT}

Risk has two dimensions, i.e. consequences and likelihood (Figure 3) (Bird \& Germain 1996; Karkoszka \& Szewieczek, 2007; ISO, 2009). Figure 3 shows the relationship between risk analysis, risk assessment and risk management. Risk analysis can be defined as the process of determining of likelihood of undesired events, harm (consequences) or loss (Bird \& Germain 1996; ISO, 2009; Rausand, 2011). Risk assessment is an overall process of risk identification, risk analysis and risk evaluation (Karkoszka \& Szewieczek, 2007). Risk management has several meanings and is often associated with obtaining insurance coverage to transfer risks (Bird \& Germain, 1996). The concept of likelihood (ISO, 2009) (or frequency) is central to risk, and frequency is given units of events per unit of time is used to define these.

Aspect and impact frequency illustrates how often the impacts will appear with an explanation that the more often an impact is released, the more important the impact is. The impacts that appear in normal condition have higher frequency than the impacts under abnormal or emergency conditions. Likelihood indicators are described in Table 1.

The analysis of consequences (Bird \& Germain, 1996; ISO, 2009) in this research shown in table 2 considers the impact hazard level based on impact characteristics so it can be known that an impact is categorized as minor, moderate, signifi-

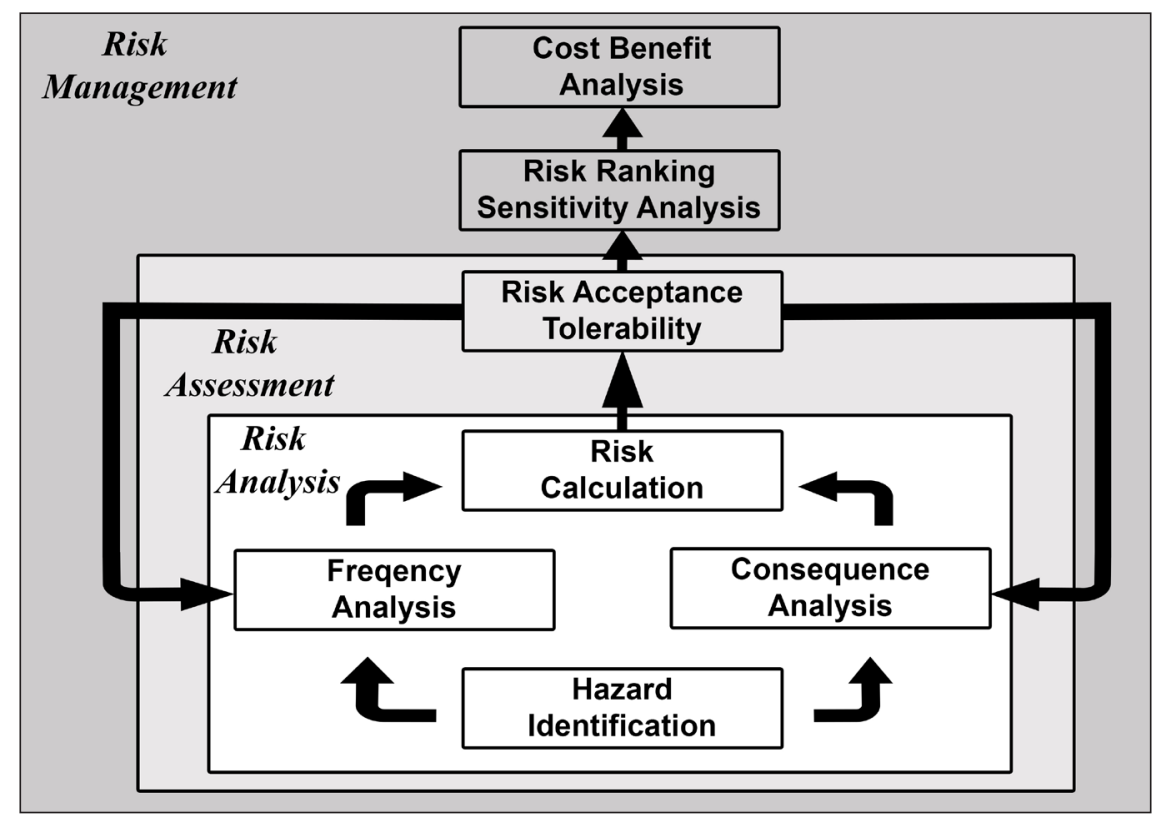

Figure 3. Relationships of risk analysis, risk assessment and risk management 
Table 1. Likelihood indicators in risk assessment at ore processing industry

\begin{tabular}{|c|c|c|c|}
\hline \multirow{4}{*}{ Frequency of potential impact } & & Seldom & May occur more than once when facility operates \\
\hline & (2) & Possible & $\begin{array}{l}\text { May occur once or more when facility operates, but less than once in } 20 \\
\text { years }\end{array}$ \\
\hline & (3) & Often & May occur once or more every 20 years but less than once a year \\
\hline & (4) & Very often & May occur once or more in every year \\
\hline \multirow{4}{*}{ Frequency description } & (1) & Seldom & Events that seldom occur $<1$ per facility operates \\
\hline & (2) & Possible & Events that may occur $<1$ per every 20 years; $>1$ per facility operates \\
\hline & (3) & Often & Events that may often occur $<1$ per year; $>1$ every 20 years \\
\hline & (4) & Very often & Occur regularly $\geq 1$ per year \\
\hline
\end{tabular}

Table 2. Consequences indicators in risk assessment at ore processing industry

\begin{tabular}{|c|c|c|c|}
\hline \multirow{4}{*}{ Financial } & (1) & Minor & $\$ 0-\$ 25 \mathrm{M}$ \\
\hline & $(2)$ & Moderate & $\$ 25-50 M$ \\
\hline & (3) & Significant & $\$ 50-\$ 100 M$ \\
\hline & (4) & Major & $>\$ 100$ \\
\hline \multirow{4}{*}{ Legal / Compliance } & (1) & Minor & Not a compliance issue on regulation requirements or informal notification \\
\hline & $(2)$ & Moderate & $\begin{array}{l}\text { Non-compliance issue on regulation requirements at moderate level by notifica- } \\
\text { tion of violation with minimum penalty }\end{array}$ \\
\hline & (3) & Significant & $\begin{array}{l}\text { Non-compliance issue that is significant with regulation requirements by notifica- } \\
\text { tion of violation with good potential }>\$ 100,000\end{array}$ \\
\hline & (4) & Major & Major and/or chronical non-compliance on administration \\
\hline \multirow{4}{*}{ Reputation } & $(1)$ & Minor & No news coverage \\
\hline & $(2)$ & Moderate & Local coverage and from stakeholder whose level is low \\
\hline & (3) & Significant & Provincial or regional level coverage or from important stakeholder \\
\hline & (4) & Major & International or national news or critics from stakeholder \\
\hline \multirow{4}{*}{ Environment } & $(1)$ & Minor & Temporary and measured impacts \\
\hline & (2) & Moderate & Short-term but repairable impacts \\
\hline & (3) & Significant & $\begin{array}{l}\text { Significant damage but the impacts outside or inside organization can be re- } \\
\text { stored back to initial condition }\end{array}$ \\
\hline & (4) & Major & Major or hazardous damage outside organization that is possibly hard to repair \\
\hline \multirow{4}{*}{ Local Community } & $(1)$ & Minor & $\begin{array}{l}\text { Minimum reaction from outside parties and mostly from individuals or there is no } \\
\text { complaints }\end{array}$ \\
\hline & (2) & Moderate & $\begin{array}{l}\text { Moderate complaints with minor media coverage and there is a dispute that oc- } \\
\text { curs }\end{array}$ \\
\hline & (3) & Significant & Significant complaint and media attention and there is a dispute that occurs \\
\hline & $(4)$ & Major & $\begin{array}{l}\text { Main complaints with international or national coverage as well as the loss of } \\
\text { social permit and/or support from community }\end{array}$ \\
\hline \multirow{4}{*}{$\begin{array}{l}\text { Stakeholders } \\
\text { (regional, national, } \\
\text { international) }\end{array}$} & (1) & Minor & $\begin{array}{l}\text { Minimum reaction from outside parties and mostly from individuals or there is no } \\
\text { complaint }\end{array}$ \\
\hline & $(2)$ & Moderate & Moderate complaint and there is a dispute that occurs from several groups \\
\hline & (3) & Significant & $\begin{array}{l}\text { Significant complaint and regional media attention and there is a dispute that } \\
\text { occurs }\end{array}$ \\
\hline & $(4)$ & Major & $\begin{array}{l}\text { Main complaints with international or national coverage as well as the loss of } \\
\text { social permit and/or support from community }\end{array}$ \\
\hline \multirow{4}{*}{ Production } & (1) & Minor & $<1 \%$ \\
\hline & (2) & Moderate & $1-5 \%$ \\
\hline & (3) & Significant & $5-90 \%$ \\
\hline & (4) & Major & Shutdown \\
\hline \multirow{4}{*}{ Schedule } & (1) & Minor & $<1$ month or delay \\
\hline & $(2)$ & Moderate & $1-3$ month \\
\hline & (3) & Significant & $3-12$ month \\
\hline & (4) & Major & $>1$ year \\
\hline
\end{tabular}


Table 3. List of environmental important aspects in ore processing industry with four-cells risk matrix method

\begin{tabular}{|c|c|c|c|c|c|c|c|}
\hline Activity & Aspect & Risk & $\begin{array}{l}\text { Conse- } \\
\text { quence }\end{array}$ & $\begin{array}{l}\text { Consequenc- } \\
\text { es catrgory }\end{array}$ & $\begin{array}{l}\text { Likeli- } \\
\text { hood }\end{array}$ & $\begin{array}{l}\text { Risk ran- } \\
\text { king }\end{array}$ & Planning \& control \\
\hline \multicolumn{8}{|c|}{ Compliance } \\
\hline $\begin{array}{l}\text { Mainentance } \\
\text { shop }\end{array}$ & $\begin{array}{l}\text { Oil water } \\
\text { separator }\end{array}$ & $\begin{array}{l}\text { Exceed permit } \\
\text { threshold during } \\
\text { compliance moni- } \\
\text { toring of process } \\
\text { outfalls }\end{array}$ & 3 & $\begin{array}{l}\text { Compliance } \\
\text { environmen- } \\
\text { tal }\end{array}$ & 3 & 9 & $\begin{array}{l}\text { Skimmer installation } \\
\text { and chamber mainte- } \\
\text { nance and clean up }\end{array}$ \\
\hline Used oil & $\begin{array}{l}\text { Utilization of } \\
\text { used oil }\end{array}$ & $\begin{array}{l}\text { Utilization hazard- } \\
\text { ous waste }\end{array}$ & 2 & Compliance & 4 & 8 & Used oil consumption \\
\hline \multicolumn{8}{|c|}{ Water } \\
\hline Settling pond & $\begin{array}{l}\text { Effluent from } \\
\text { pond }\end{array}$ & $\begin{array}{l}\text { Impact to estuary } \\
\text { water quality }\end{array}$ & 3 & $\begin{array}{l}\text { Compliance } \\
\text { environmen- } \\
\text { tal }\end{array}$ & 2 & 6 & $\begin{array}{l}\text { Routine mainte- } \\
\text { nance; sludge dreg- } \\
\text { ing }\end{array}$ \\
\hline $\begin{array}{l}\text { Spillage of } \\
\text { petroleum, } \\
\text { hazardous } \\
\text { waste, haz- } \\
\text { ardous mate- } \\
\text { rials }\end{array}$ & \begin{tabular}{|l|} 
Petroleum, \\
hazardous \\
waste and \\
materials \\
transport, \\
shut-down, \\
storage tanks, \\
and barge \\
(abnormal)
\end{tabular} & $\begin{array}{l}\text { Spill could impact } \\
\text { to surface water } \\
\text { and soil }\end{array}$ & 2 & $\begin{array}{l}\text { Environmen- } \\
\text { tal }\end{array}$ & 3 & 6 & $\begin{array}{l}\text { Frequent check for } \\
\text { tanks before trans- } \\
\text { port; storage tanks } \\
\text { inspection and NDT } \\
\text { (non-destructive } \\
\text { testing) and condi- } \\
\text { tion monitoring, spill } \\
\text { response protocol } \\
\text { and team, secondary } \\
\text { containment }\end{array}$ \\
\hline $\begin{array}{l}\text { Fuel and } \\
\text { concentrate } \\
\text { transport by } \\
\text { pipeline }\end{array}$ & $\begin{array}{l}\text { Spill of fuel } \\
\text { and concen- } \\
\text { trate } \\
\text { (abnormal) }\end{array}$ & $\begin{array}{l}\text { Contamination to } \\
\text { soil and water }\end{array}$ & 2 & $\begin{array}{l}\text { Financial } \\
\text { environmen- } \\
\text { tal }\end{array}$ & 3 & 6 & HSE patrol \\
\hline Lime plant & Lime spillage & $\begin{array}{l}\text { Reduce the quality } \\
\text { of groundwater }\end{array}$ & 1 & $\begin{array}{l}\text { Environmen- } \\
\text { tal }\end{array}$ & 4 & 4 & $\begin{array}{l}\text { Contamination water } \\
\text { use to neutralization }\end{array}$ \\
\hline \multicolumn{8}{|c|}{ Air } \\
\hline $\begin{array}{l}\text { Lime plant } \\
\text { and dewater- } \\
\text { ing plant }\end{array}$ & $\begin{array}{l}\text { Emission } \\
\text { (normal) }\end{array}$ & Ambient air quality & 2 & Compliance & 3 & 6 & $\begin{array}{l}\text { Scrubber and filter } \\
\text { bag house mainte- } \\
\text { nance; stack emis- } \\
\text { sion test }\end{array}$ \\
\hline $\begin{array}{l}\text { Dewatering } \\
\text { plant }\end{array}$ & $\begin{array}{l}\text { Concentrate } \\
\text { movement to } \\
\text { loading dock }\end{array}$ & Ambient air quality & 2 & $\begin{array}{l}\text { Environmen- } \\
\text { tal }\end{array}$ & 3 & 6 & $\begin{array}{l}\text { Improving contain- } \\
\text { ment on conveyors } \\
\text { system; closed sys- } \\
\text { tem for drainage and } \\
\text { sump pump optimi- } \\
\text { zation }\end{array}$ \\
\hline Ore stockpile & Fugitive dust & Ambient air quality & 1 & $\begin{array}{l}\text { Environmen- } \\
\text { tal }\end{array}$ & 4 & 4 & $\begin{array}{l}\text { Water sprayer instal- } \\
\text { lation and mainte- } \\
\text { nance }\end{array}$ \\
\hline $\begin{array}{l}\text { Dewatering } \\
\text { plant }\end{array}$ & $\begin{array}{l}\text { Emission (ab- } \\
\text { normal) }\end{array}$ & $\begin{array}{l}\text { Exceed permit } \\
\text { threshold during } \\
\text { compliance moni- } \\
\text { toring of process }\end{array}$ & 1 & Compliance & 3 & 3 & $\begin{array}{l}\text { Cyclone and wet } \\
\text { scrubber mainte- } \\
\text { nance and control }\end{array}$ \\
\hline $\begin{array}{l}\text { Fire assay } \\
\text { laboratory }\end{array}$ & $\begin{array}{l}\text { Emissions } \\
\text { and fugitive } \\
\text { dust }\end{array}$ & $\begin{array}{l}\text { Emissions from } \\
\text { fume hood and } \\
\text { dust control }\end{array}$ & 1 & Compliance & 2 & 2 & $\begin{array}{l}\text { Indoor air quality } \\
\text { monitoring }\end{array}$ \\
\hline Lime plant & $\begin{array}{l}\text { Emission } \\
\text { (abnormal) }\end{array}$ & $\begin{array}{l}\text { Impact to emission } \\
\text { standard }\end{array}$ & 1 & Compliance & 2 & 2 & $\begin{array}{l}\text { Filter bag house re- } \\
\text { placement and main- } \\
\text { tenance }\end{array}$ \\
\hline \multicolumn{8}{|c|}{ Waste } \\
\hline Instrument & $\begin{array}{l}\text { Radioactivity } \\
\text { exposure or } \\
\text { release } \\
\text { (abnormal) }\end{array}$ & $\begin{array}{l}\text { Radioactivity ex- } \\
\text { posure }\end{array}$ & 1 & $\begin{array}{l}\text { Environmen- } \\
\text { tal }\end{array}$ & 3 & 3 & None \\
\hline Laboratories & $\begin{array}{l}\text { Discarded } \\
\text { solid samples }\end{array}$ & Soil quality & 1 & $\begin{array}{l}\text { Environmen- } \\
\text { tal }\end{array}$ & 2 & 2 & $\begin{array}{l}\text { Reclaimed unused } \\
\text { mineral samples } \\
\text { are discarded to ore } \\
\text { stockpile }\end{array}$ \\
\hline
\end{tabular}


cant and major, and is based on the impact spread area, i.e. how wide and how many environmental components will be influenced. These consequences consist of eight categories:

1. Financial aspect, i.e. the number of economic impacts on the organization.

2. Legal or compliance aspect, i.e. whether there is a difficulty to comply with the regulation and permit requirements.

3. Reputation aspect, i.e. company profile.

4. Environmental aspect, the number of impacts on the environment.

5. Local community aspect, i.e. assessment from media or community related to environmental issues.

6. Stakeholder aspect, i.e. assessment from international and/or national media for environmental issues.

7. Production aspect.

8. Schedule aspect in the form of delay on production.

Risk ranking is a powerful technique used to simplify the risk analysis process (Bird \& Germain, 1996), it can be used as part following a likelihood identification, to arrive at a list of control and planning, prioritised according to the risk (Haddad et al, 2012; Nota \& Gregorio, 2010). The simplest form (Figure 3 ) is a four-cell matrix where the cells in one direction represent increasing degrees of severity of consequences, while the cells in the other direction show an increasing likelihood. The factor $n$, is an attempt to further weight the index in order to represent the public's aversion to multiply environmental impacts.

The parameters of impacts and costs represent the economic interest or company business, according to the ISO 14001:2015 objectives that there has to be a balance between economic interest and environment. The final product of aspect evaluation stage is the list of environmental important aspects, which may be enumerated from the most important to the less important, based on the achieved score as described in Table 3. It shows that the company has succeeded in creating priority of many works and is the objective of clause 6, i.e. planning on ISO 14001:2015.

\section{CONCLUSION}

Identification of the environmental impacts is the implementation of clause 6.1.2 from ISO 14001:2015 environmental management system where the comprehensiveness of system, coverage compliance and work priority result from this standard clause. The success of a system strongly depends on a good understanding on the environmental aspects and impacts. The result of risk assessment can be used as reference and data information in operation control determination and administration control to minimize the risks related to the impacts of environmental aspects in ore processing industry.

\section{REFERENCES}

1. Bird Jr. F.E., Germain L.G. 1996. Loss Control Management, Practical Loss Control Leadership. Revised Edition., Georgia: Det Norske Veritas (USA), Inc.

2. Galante E.B.F., Haddad A.N. 2017. Environmental Management System: Risk Evaluation Integrated to Life-Cycle Assessment. WIT Transaction on Engineering Sciences, 88, 411-418.

3. Haddad A., Galante E., Caldas R., Morgado C. 2012. Hazard Matrix Aplication in Health, Safety and Environmental Management Risk Evaluation. InTech, 19-50.

4. International Standard Organization (ISO), 2006a. Environmental Management - Life Cycle Assessment: Requirements and Guideline. ISO 14044:2006, Geneva.

5. International Standard Organization (ISO). 2006b. Environmental Management - Life Cycle Assessment: Principles and Framework. ISO 14040:2006, Geneva.

6. International Standard Organization (ISO). 2009. Risk Management - Principles and Guideline. ISO 31000 :2009, Geneva.

7. International Standard Organization (ISO). 2015. Environmental Management System - Requirements with Guidance for Use. ISO 14001 :2015, Geneva.

8. Karkoszka T., Szewieczek D. 2007. Risk of the Prossesses in the Aspect of Quality, Natural Environment and Occupational Safety. Journal of Achievement in Materials and Manufacturing Engineering, 20(1-2), 539-542.

9. Nota G., Gregorio M.P.D. 2010. A Model for Process Oriented Risk Management. Advances in Risk Management, InTech, 19-36.

10. Rausand M. 2011. Risk Assessment Theory, Methods, and Applications. John Wiley \& Sons, New Jersey.

11. Susanto A., Putro E.K., Wulan R.N., Yochu W.E. 2012. Globally Harmonized System (GHS) Implementation and Management of Hazardous Sus- 
btances (B3) in Concentrating Division PT Freeport Indonesia. Proc. 1st International Conference on Sustainable Agriculture and Environment, 302-308.

12. Susanto A., Suryanegara D., Putro E.K. 2013. Indoor Air Quality Control Laboratory Concentrating Division PT Freeport Indonesia. Proc. the 2nd International Conference on Sustainable Infrastructure and Built Environment, 373-376.

13. Susanto A., Jatmiko F., Putro E.K. 2015. Lead Exposure on Fire Assay Laboratory Workers. Proc. 2nd Asean Conference on Safety and Education in Laboratory, A20.

14. Susanto A., Purwanto P., Sunoko H.R., Setiani O. 2016a. Diesel Engine Exhaust Emissions Survey of Underground Mine in Indonesia. Journal of Industrial Pollution Control, 32(2), 608-616.
15. Susanto A., Wulan R.N., Putro E.K. 2016b. Used Oil Utilization for Lime Production as Hazardous Waste Minimization. International Journal of Waste Resources, 6(4), 252.

16. Susanto A. 2017. Information Management on Environmental Perfomance in Concentrating Division PT Freeport Indonesia. Theses. School of Business and Management, Institut Teknologi Bandung, Bandung.

17. Susanto A., Purwanto P., Sunoko H.R., Setiani O. 2017. A Kriging Method for Mapping Underground Mine Air Pollution. Advanced Science Letters, 23(3), 2329-2332.

18. Susanto A., Putro E.K. 2017. Identifikasi Aspek dan Dampak Lingkungan untuk Perencanaan Pengendalian Risiko Kesehatan Kerja pada Laboratorium Assay Divisi Concentrating PT Freeport Indonesia. IIHA Conference, Exhibition, and Training 2017. 